\title{
What's So Special about China's Exports?
}

\section{Citation}

Rodrik, Dani. 2006. “What's So Special about China's Exports?” China and World Economy 14 (5): 1-19. https://doi.org/10.1111/j.1749-124x.2006.00038.x.

\section{Permanent link}

http://nrs.harvard.edu/urn-3:HUL.InstRepos:37931110

\section{Terms of Use}

This article was downloaded from Harvard University's DASH repository, and is made available under the terms and conditions applicable to Other Posted Material, as set forth at http:// nrs.harvard.edu/urn-3:HUL.InstRepos:dash.current.terms-of-use\#LAA

\section{Share Your Story}

The Harvard community has made this article openly available.

Please share how this access benefits you. Submit a story.

Accessibility 


\title{
NBER WORKING PAPER SERIES
}

\section{WHAT'S SO SPECIAL ABOUT CHINA'S EXPORTS?}

\author{
Dani Rodrik \\ Working Paper 11947 \\ http://www.nber.org/papers/w11947 \\ NATIONAL BUREAU OF ECONOMIC RESEARCH \\ 1050 Massachusetts Avenue \\ Cambridge, MA 02138 \\ January 2006
}

The views expressed herein are those of the author(s) and do not necessarily reflect the views of the National Bureau of Economic Research.

(C2006 by Dani Rodrik. All rights reserved. Short sections of text, not to exceed two paragraphs, may be quoted without explicit permission provided that full credit, including $\odot$ notice, is given to the source. 
What's So Special about China's Exports?

Dani Rodrik

NBER Working Paper No. 11947

January 2006

JEL No. F1, O4

\begin{abstract}
$\underline{\text { ABSTRACT }}$
Much more than comparative advantage and free markets have been at play in shaping China's export success. Government policies have helped nurture domestic capabilities in consumer electronics and other advanced areas that would most likely not have developed in their absence. As a result, China has ended up with an export basket that is significantly more sophisticated than what would be normally expected for a country at its income level. This has been an important determinant of China's rapid growth. What matters for China's future growth is not the volume of exports, but whether China will continue to latch on to higher-income products over time.

Dani Rodrik

John F. Kennedy School of Government

Harvard University

79 JFK Street

Cambridge, MA 02138

and NBER

dani_rodrik@harvard.edu
\end{abstract}




\section{WHAT'S SO SPECIAL ABOUT CHINA's EXPORTS?* \\ Dani Rodrik \\ Harvard University \\ Revised, January 2006}

\section{$\underline{\text { I. Introduction }}$}

The phenomenal performance of China constitutes the great economic miracle of the last quarter century. China's economy has expanded by leaps and bounds, at historically unprecedented rates that few economists would have found plausible or feasible ex ante. More importantly, this growth has lifted hundreds of millions of people from deep poverty and has helped improve health, education, and other social standards. China has accomplished all this using its own brand of experimental gradualism--increasingly relying on markets and on price signals, yet until very recently doing so within the boundaries of a highly unorthodox set of institutions.

That trade has played a significant role in this transformation is beyond dispute. China would likely have grown even if the global economy had been closed. And the very early stages of Chinese growth, based on rural reform, did not in any significant way rely on global markets. But from the mid-1980s on, one must suppose that China's growth was fueled and sustained by the opportunities that the world market offered. We can see the increasing footprint of foreign trade and investment in all the major aggregates. The share of exports in GDP rose from virtually nothing in the 1960 s to close to 30 percent in 2003, a rate of increase that is much larger than what has been experienced elsewhere in the world (see Figure 1). Inward direct foreign investment has risen from close to zero in the early 1980s to around 5 percent of GDP. The flip

\footnotetext{
" This is a paper prepared for the project on "China and the Global Economy 2010" of the China Economic Research and Advisory Programme. I am indebted to Edwin Lim for his guidance and comments, and to the Programme for financial support. Comments from Yu Yongding and Adrian Wood have also been very helpful. Oeindrila Dube performed superb research assistance.
} 
side of these figures is that China has become one of the world's biggest trading powers, accounting for $6 \%$ of global trade flows (Figure 2).

$\underline{\text { Figure } 1}$

Exports as a share of GDP

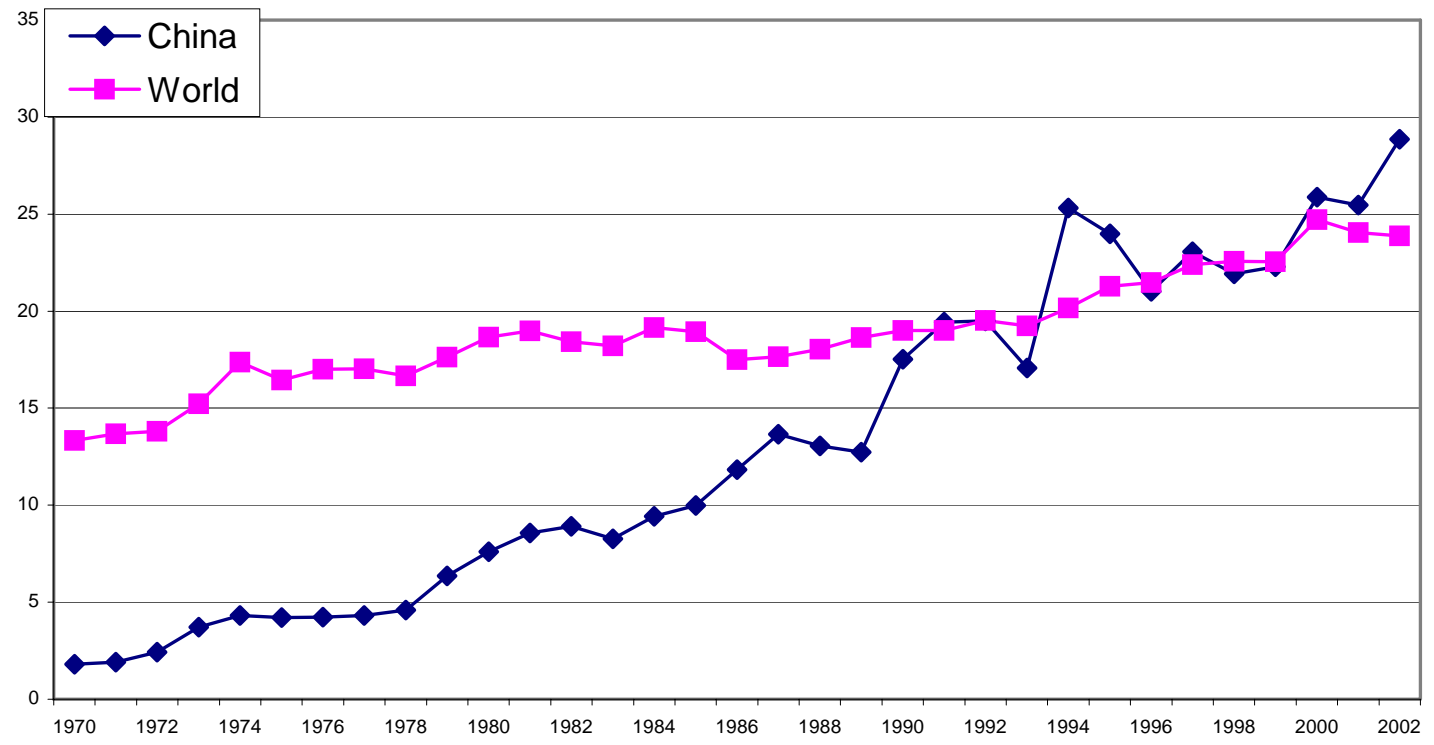

Source: World Development Indicators Database

$\underline{\text { Figure } 2}$

China's share of world merchandise exports

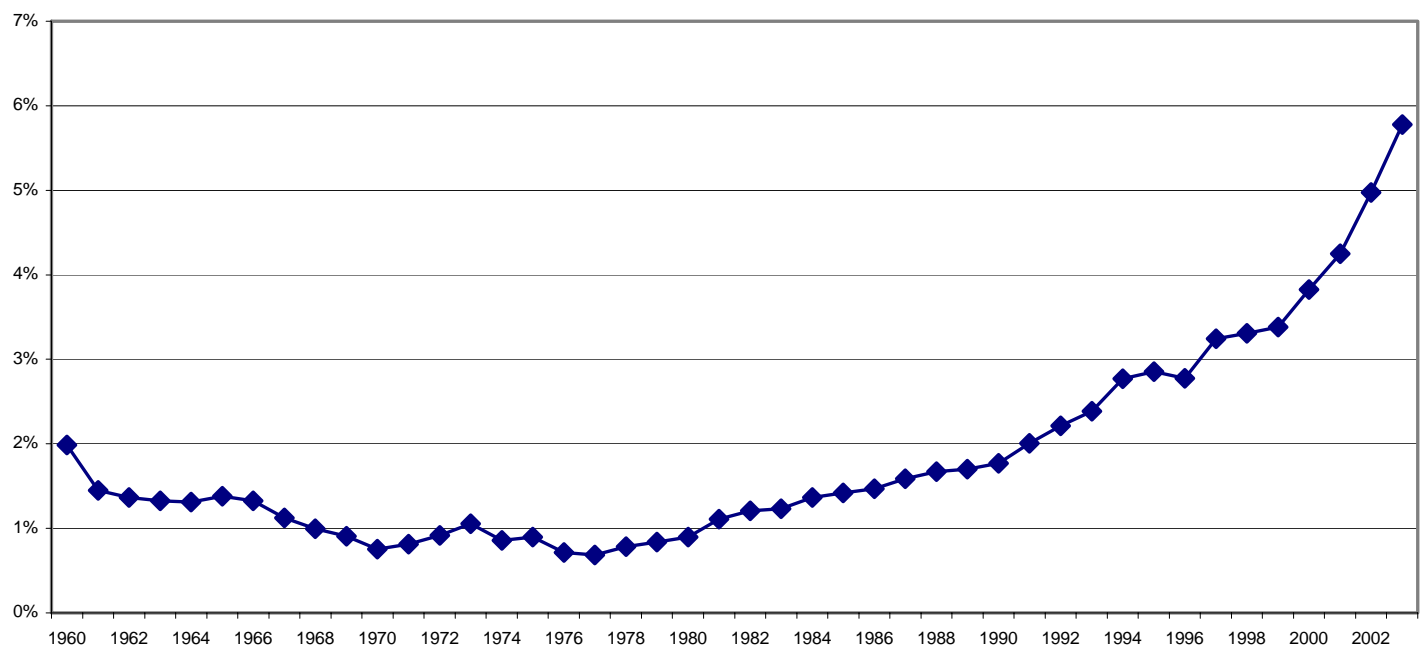

Source: World Development Indicators Database 
The success with which China has integrated itself into the world economy raises many questions. Drawing the real lessons from this experience is important, not only because China is the stellar example which other developing countries are trying to emulate, but also because the shape of China's own future policies depend (or should depend) on these lessons.

The task is not made easier by the highly unconventional manner in which China has achieved its global integration. The standard list of recommendations for countries pursuing this goal includes: dismantling quantitative restrictions on imports, reducing import tariffs and their dispersion, making the currency convertible for current account transactions, eliminating bureacratic red tape and other impediments to direct foreign investment, improving customs procedures, and establishing the rule of law. Measured by these guidelines, China's policies resemble more those of a country that messed up big time than those of a country that became a formidable competitive threat in world markets to rich and poor countries alike. In brief, China opened up very gradually, and significant reforms lagged behind growth (in exports and overall incomes) by at least a decade or more. While monopoly state trading was liberalized relatively early (starting in the late 1970s), what took its place was a complex and highly restrictive set of tariffs, non-tariff barriers, and licenses. These were not substantially relaxed until the early 1990s.

Table 1 shows the trend for import tariffs: In the early 1990s, tariffs still averaged above 40 percent (among the highest in the world at the time), with significant dispersion and a maximum rate above $200 \%$. While the home market was highly protected, the penalizing effect of these tariffs on export production was neutralized through duty drawbacks and other incentives for export oriented investment projects. Currency markets were not unified until 1994. Foreign investors were straddled with requirements to form joint ventures, transfer 
technology to local partners, and source their inputs locally. And corruption and weak rule of law remain significant problems. So China is not a straightforward story of export growth achieved through trade openness and free market forces.

Table 1: China’s import tariffs

\begin{tabular}{|l|c|c|c|c|}
\hline & $\begin{array}{c}\text { Unweighted } \\
\text { average }\end{array}$ & $\begin{array}{c}\text { Weighted } \\
\text { average }\end{array}$ & $\begin{array}{c}\text { Dispersion } \\
\text { (st. dev) }\end{array}$ & Maximum \\
\hline 1982 & 55.6 &.. &.. &.. \\
\hline 1985 & 43.3 &.. &.. &.. \\
\hline 1988 & 43.7 &.. &.. &.. \\
\hline 1991 & 44.1 &.. & 29.9 &.. \\
\hline 1992 & 42.9 & 40.6 & 27.9 & 220.0 \\
\hline 1993 & 39.9 & 38.4 &.. &.. \\
\hline 1994 & 36.2 & 35.5 & 17.4 & 121.6 \\
\hline 1995 & 35.2 & 26.8 & 13.0 & 121.6 \\
\hline 1996 & 23.6 & 22.6 & 13.0 & 121.6 \\
\hline 1997 & 17.6 & 16.0 &.. &.. \\
\hline 1998 & 17.5 & 15.7 & 12.1 & 121.6 \\
\hline 2000 & 16.4 &.. & 9.1 & 70.0 \\
\hline 2001 & 15.3 & 9.1 & 6.4 & \\
\hline 2002 & 12.3 & & & \\
\hline
\end{tabular}

Source: Prasad (2004), p. 10.

Neither is China a simple story of specialization according to comparative advantage. While labor intensive exports (toys, garments, simple electronics assembly) have always played an important role in China's export basket, China also exports a wide range of highly sophisticated products. Indeed, a major argument of this paper is that China is an outlier in terms of the overall sophistication of its exports: its export bundle is that of a country with an incomeper-capita level three times higher than China's. China has somehow managed to latch on to advanced, high-productivity products that one would not normally expect a poor, labor abundant country like China to produce, let alone export. I will provide some evidence below that 
suggests this has been an important contributor to China's recent growth. China's experience indicates that it not how much you export, but what you export that matters.

The extent to which China's sophisticated export basket has been a direct consequence of its unorthodox policy regime is not clear. But it is not too much of a stretch to imagine that China's industrial structure has indeed been shaped by policies of promotion and protection, just as in the cases of earlier East Asian tigers. I will return to this theme at the end of the paper, and offer some general remarks that may help frame future policy decisions in the general areas of trade and industrialization.

The outline of this paper is as follows. In section II, I will provide a quantitative evaluation of China's export structure in comparative context and argue that China's trade pattern cannot be explained solely by factor endowments and other "economic fundamentals." In section III, I will provide some evidence that links the types of goods that countries export with their growth performance, and show that China has benefited from having developed export industries that one would not normally associate with a country at that level of income. Section IV briefly reviews the development of the consumer electronics industry in China to put some flesh on the statistical picture developed in previous sections and to highlight the role of government policies. Section V provides concluding remarks and derives some implications for Chinese policymakers.

\section{The indeterminacy of comparative advantage}

Consider how a country's pattern of specialization and trade is determined. The principle of comparative advantage dictates that trade patterns are determined by how relative costs of production within a country differ from those in the rest of the world. These differences are in 
turn linked to differences in productivity levels across industries (as in the Ricardian model of trade) or to differences in relative factor endowments across countries (as in the Heckscher-Ohlin model). In these models, entrepreneurs observe costs directly and make their investment decisions accordingly.

But in a poor developing country, investors contemplating entry into new, non-traditional activities face considerable uncertainty about the costs of operation. These costs will likely depend not just on factor endowments, but also on the investor's success with technology adoption and adaptation, on the policy environment, and (perhaps also) on the number of other investors making similar investment choices. The risks that arise from such uncertainty are borne disproportionately by early entrants into new industries, who therefore provide valuable informational spillovers to the rest of the economy. If they are successful, later entrants can observe the profitability of the incumbents and emulate them. If they fail, they pay the full cost of their failure. This externality implies that market forces on their own generate too little investments in new activities; to use the terminology of Hausmann and Rodrik (2003), they induce too little "self-discovery." The result is that low-income countries produce too few highproductivity goods that they could be producing (and selling in world markets) and incomes are lower than they would otherwise be. Conversely, rapidly growing countries are those that are able to somehow generate the investments in these non-traditional, higher-productivity tradables.

To put some empirical flesh on these conceptual ideas, Ricardo Hausmann and I have recently developed an indicator that measures the productivity level associated with a country's export basket. This indicator, which we call EXPY is calculated in two steps. First, for each 6digit commodity that is traded we compute the weighted average of the incomes of the countries exporting that commodity, where the weights are the revealed comparative advantage of each 
country in that commodity (normalized so that the weights sum up to 1 ). This gives us the income level of that commodity, which we call PRODY. The 6-digit level of classification yields more than 5,000 products for which PRODY can be calculated. Next we calculate EXPY as the weighted average of the $P R O D Y$ for each country, where the weights are the share of each commodity in that country's total exports. More details on the construction of these indices are provided in the appendix.

As would be expected, EXPY is strongly correlated with per-capita income: rich countries export goods that other rich countries export. Figure 3 shows the scatter plot of EXPY against per-capita GDP for 1992. The correlation coefficient is 0.83 . But countries do not neatly lie alongside the regression line. Some countries are way below the regression line, while others are way above it. In the latter group, India and China stand out. It is striking that these two highperforming economies have export profiles that are especially skewed towards high productivity goods. In 1992, China's exports were associated with an income level that is more than six times higher than China’s per-capita GDP at the time. As we shall see, this gap has diminished somewhat over time, but it still remains high. 
Figure 3: Relationship between EXPY and per-capita incomes in 1992

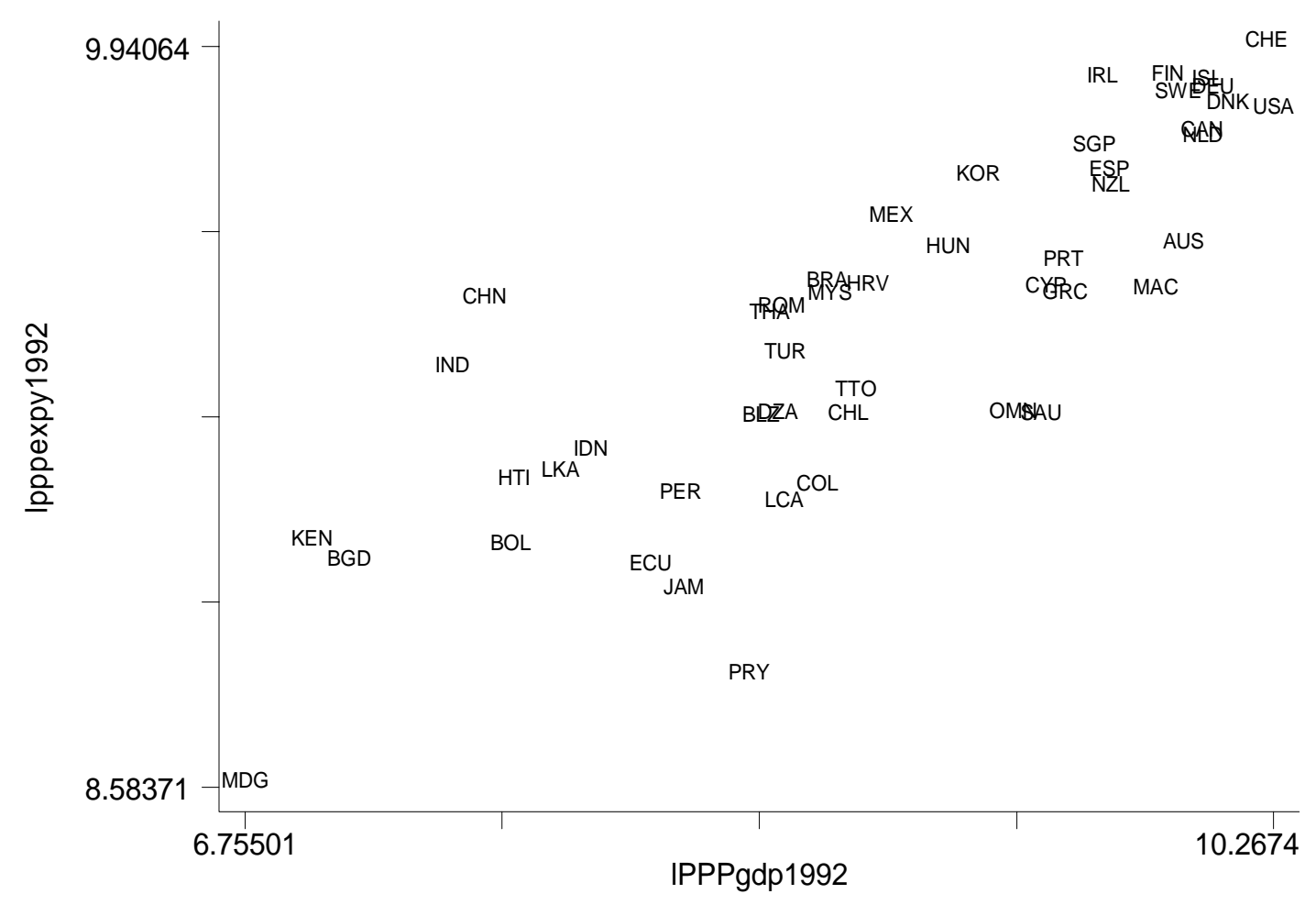

Neither is EXPY well explained by other economic fundamentals that one can think of.

Figures 4 and 5 show the partial correlations between EXPY and human capital and institutional quality, respectively, controlling for per-capita GDP. These scatter plots use more recent trade data from 2002 to maximize the sample of countries. We find a very weak positive partial correlation with the stock of human capital (Figure 4) and virtually no partial correlation with our index of institutional quality, the "rule of law" (Figure 5). Hence the evidence on the fundamentals is mixed. While the productivity of a country's exports is determined in part by its overall productive capacity and its human capital endowment, idiosyncratic characteristics also matter. To take one telling example, a country like Bangladesh with a much similar set of relative factor endowments_-abundant in labor, and scarce in human and physical capital_-has an $E X P Y$ that is roughly 50\% lower than China's. It is clear that whatever these idiosyncratic 
features may be (about which I speculate below), they seem to have China with an inordinately high level of EXPY. ${ }^{1}$ In turn, this has apparently been an important driver of its recent economic growth as I will show in the next section.

Figure 4: Partial scatter plot between EXPY and human capital

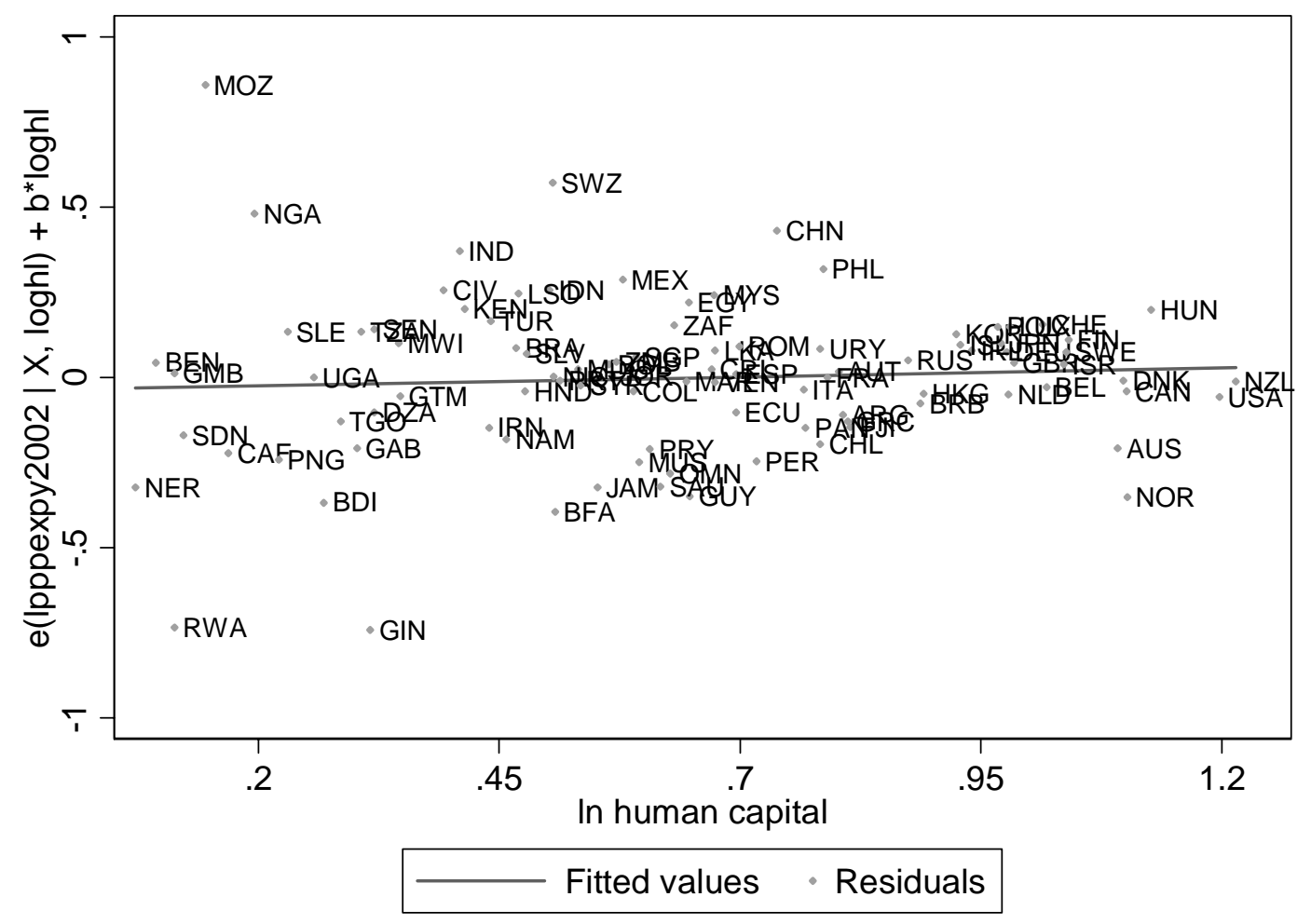

\footnotetext{
${ }^{1}$ Lo and Chan (1998) also emphasize that China's trade structure cannot be explained only by comparative advantage, and they emphasize (like I do below) the role of production- and technology-oriented policies of the government.
} 
Figure 5: Partial scatter plot between EXPY and institutional quality

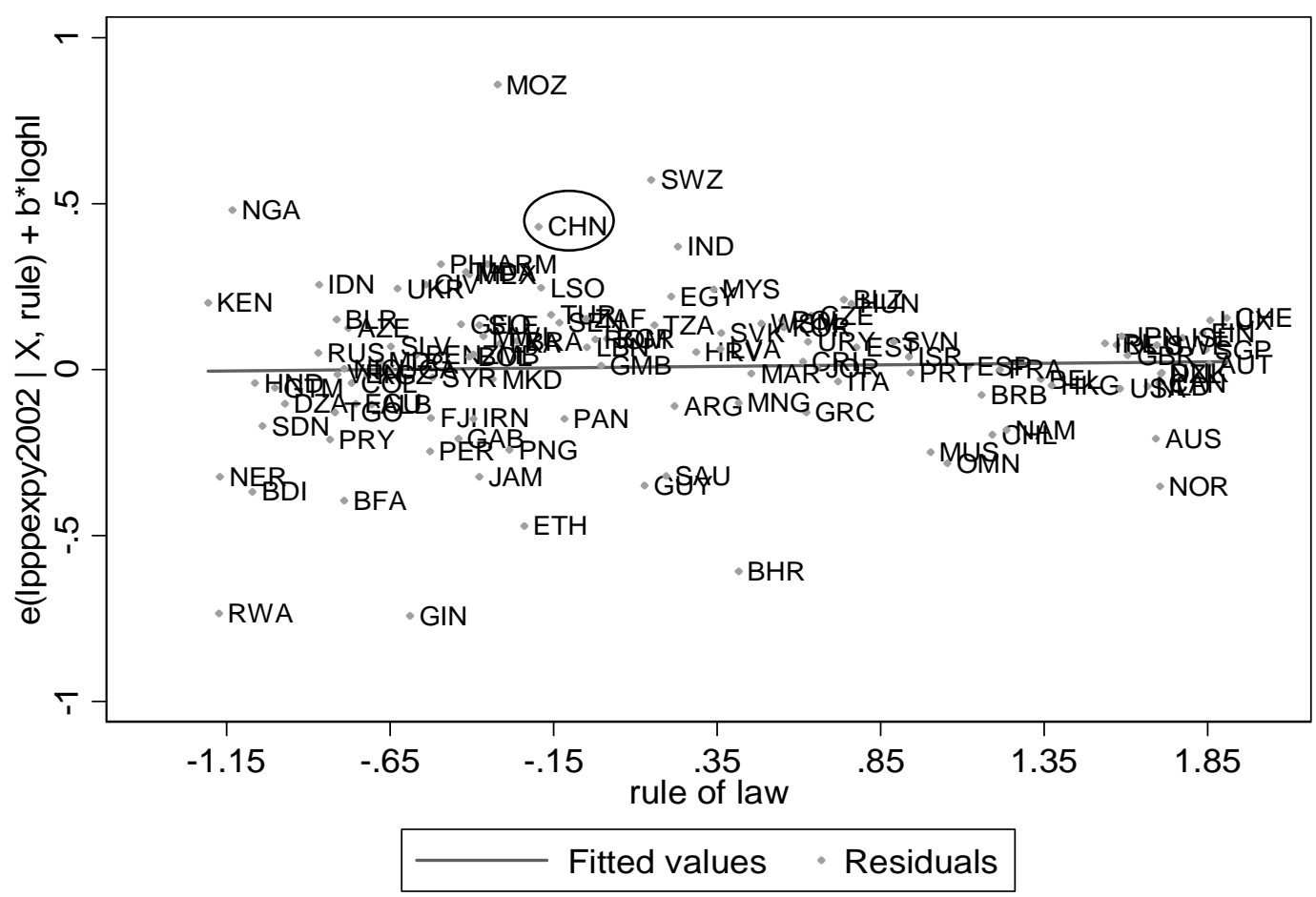

It is also interesting to compare the progress over time of China's EXPY with that of some of its important competitors. This is done in Figure 6, which shows the trends for EXPY in China, India, Hong Kong, and South Korea. China has experienced the most rapid rate of growth in the sophistication of its exports since 1992. While China still lags behind South Korea and Hong Kong, the difference in EXPY has steadily closed over time. Moreover, the gap between China and India has actually increased over the past decade. ${ }^{2}$

\footnotetext{
${ }^{2}$ Note that EXPY is calculated using commodity exports, so India's software exports are not included in this comparison. Presumably, India's EXPY would be significantly higher with software included.
} 
$\underline{\text { Figure } 6}$

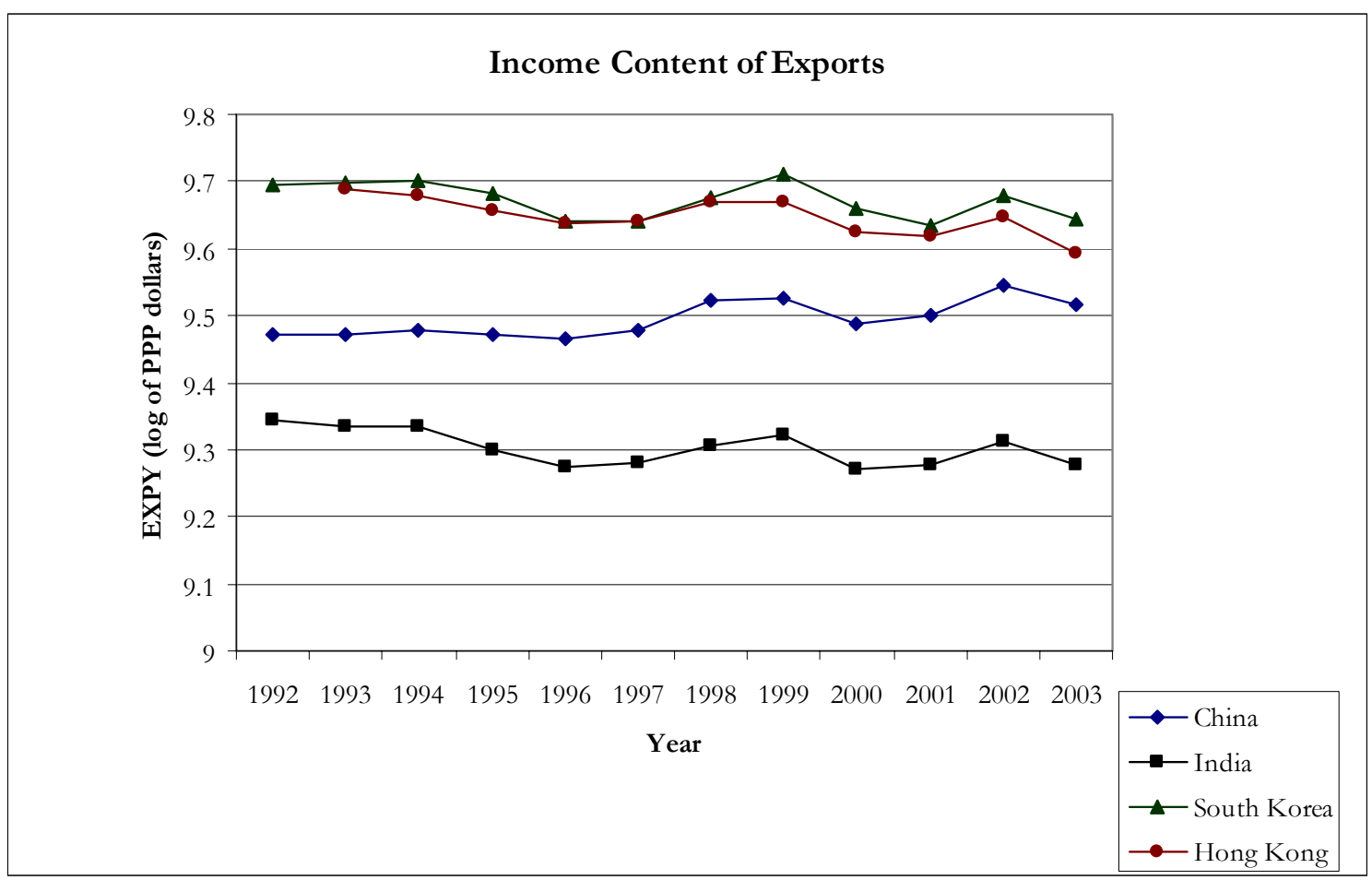

The findings here contrast with those of Wood (2001), who has argued that China's export performance in skill-intensive products is below the level that would be expected on the basis of the country's factor endowments. Wood's analysis is based on a cross-national benchmark derived from regressing the ratio of skill-intensive to labor-intensive exports on a measure of skill per worker in that country. Wood reports that China's actual share of skillintensive exports within manufactures in 1990 stood at 33 percent, compared to a predicted ratio of 40 percent (Wood 1991, Table 5). One plausible reason for the difference in the results is that Wood's method relies on a binary classification of goods (skill-intensive or not). Furhermore, the classification is carried out at a much more aggregate level than here. (Remember that we calculate EXPY using the information from more than 5,000 distinct products.) In practice, it is common for skill-intensive components of some "goods" to be done in one country and the less 
skill-intensive components in others, as Wood himself notes $(1991,10)$. An analysis at the 6digit level of disaggregation is more likely to capture these distinctions.

It is worth noting however that there are often significant quality differences even within 6-digit product categories. Even at this level of aggregation, Chinese exports often concentrate on the more labor-intensive, less sophisticated end of the product spectrum, at least when we compare them to the exports of significantly richer countries. Table 2 shows unit value comparisons for some of China's leading electronics exports. In most cases, China's unit values are lower than those of South Korea, Malaysia, or Singapore. There is therefore some truth to the argument that Chinese exports of electronics products tend to be low-cost, high volume products with not much technological sophistication, and that they therefore pose little threat to U.S. pre-eminence (see Lardy 2004). But here too there are interesting exceptions. For example, Chinese exports of video recorders and TV and video monitors have higher unit values than South Korean exports in these product lines. And in any case, what is surprising is that a country at China's income level is able to export such electronics products in the first place. That is hardly the norm for other countries with similar factor endowments, as the cross-country comparisons above show. 
Table 2: Unit value comparisons: electrical goods and equipment exports (US\$ per unit, 2003)

\begin{tabular}{|c|c|c|c|c|}
\hline product name & China & S. Korea & Malaysia & Singapore \\
\hline Electric transformers, static converters and rectifier & 0.855 & 5.713 & 0.884 & 0.229 \\
\hline Electric accumulators & 1.317 & 2.519 & 17.295 & 1.248 \\
\hline Electric apparatus for line telephony, telegraphy & 14.488 & 66.581 & 46.995 & 36.496 \\
\hline Electronic sound reproducing equipment, non-recording & 13.520 & 50.003 & 52.966 & 68.260 \\
\hline Video recording and reproducing apparatus & 48.733 & 39.356 & 90.926 & 112.492 \\
\hline Parts, accessories of audio, video recording equipment & 9.875 & 26.222 & 14.299 & n.a. \\
\hline Radio and TV transmitters, television cameras & 62.040 & 259.014 & 117.773 & 92.389 \\
\hline Radio, radio-telephony receivers & 7.370 & 38.552 & 83.770 & 68.803 \\
\hline Television receivers, video monitors, projectors & 72.903 & 17.987 & 144.185 & 195.939 \\
\hline Parts for radio, tv transmission, receive equipment & 31.982 & 47.988 & 15.007 & n.a. \\
\hline Electronic printed circuits & 1.774 & 65.973 & 2.281 & 49.581 \\
\hline Electronic integrated circuits and microassemblies & 1.101 & 960.988 & 1.478 & 2.337 \\
\hline
\end{tabular}

\section{Source: UN Comtrade Database.}

\section{It is not how much but what you export that matters}

How do we know that the productivity level of a country's exports (measured by EXPY) matters to economic performance? It turns out that there is a robust relationship between the initial level of a country's EXPY and the subsequent rate of economic growth experienced by that country. Figure 7 is the relevant scatter plot: it shows the relationship between EXPY in 1992 and growth over the 1992-2003 period, holding initial levels of income constant. This is a positive and statistically significant relationship (at the 95\% confidence level). The estimated coefficient implies that a doubling of the productivity level of a country's exports results in an increase in its overall per-capita GDP growth of around 6 percent. Therefore, had China exported only those goods that countries at China's level of income tend to export, its growth rate would have been significantly lower. As the chart shows, a high level of EXPY does not fully account for China's growth performance over this period-the other significant outlier is Ireland--but it does help explain it. 
Figure 7: Relationship between initial level of EXPY and growth, controlling for initial income

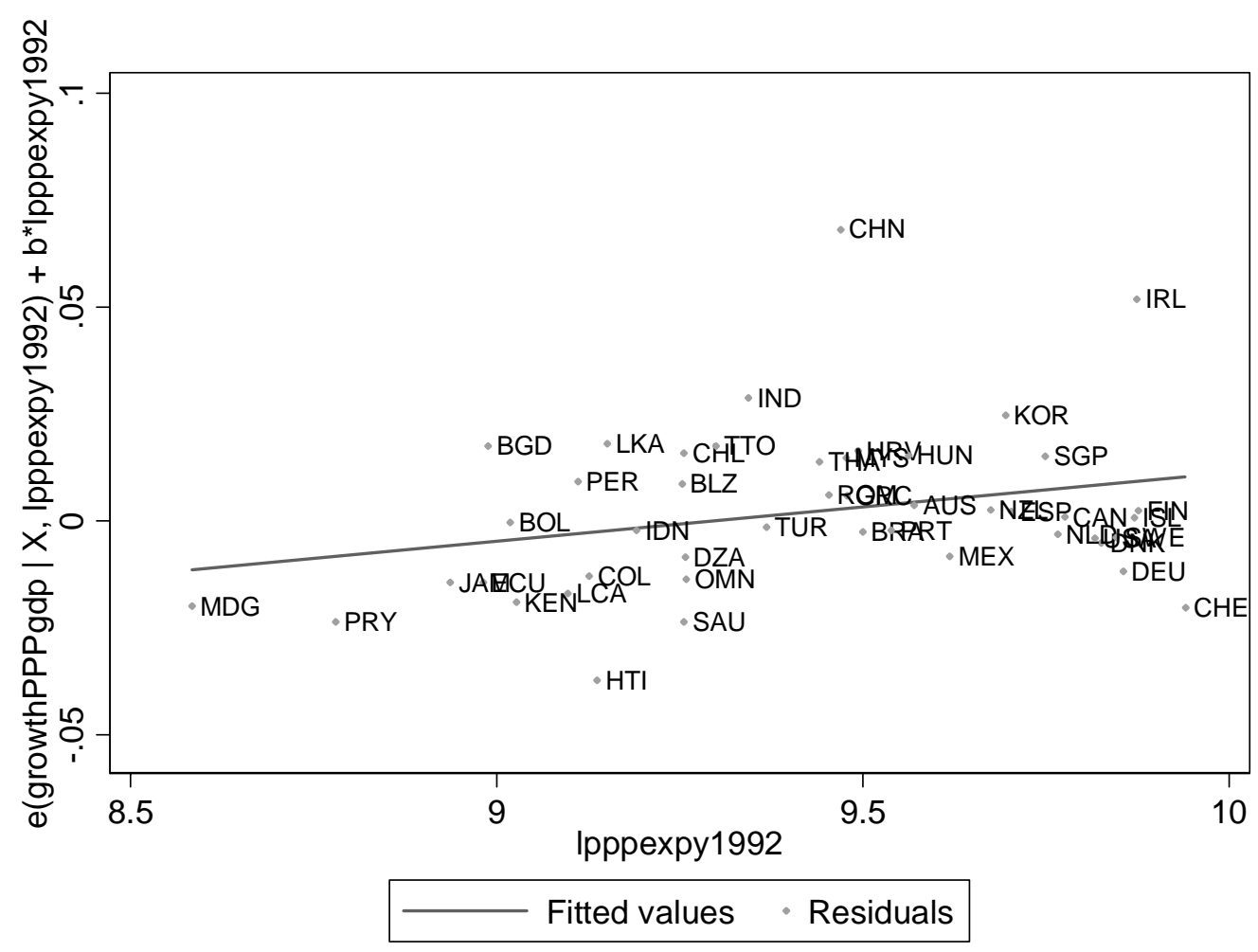

Is this a truly causal relationship? Even though the regressor is the level of EXPY at the beginning of the period, it is still possible that causality goes from growth to EXPY rather than the other way around (if growth and EXPY are both persistent over time). To rule this possibility out, we can use an instrumental variable approach, which requires locating an exogenous variable that plausibly influences growth only through the impact it has on EXPY. Population (or population density) is in fact one such instrument. The basic economic theory underlying this is simple. Go back to the original story of how comparative advantage is determined in part by a process of cost discovery by initial entrants in a new industry. High productivity “discoveries" naturally attract more emulation, and the productivity of an economy's tradable sector tends to converge towards the productivity level of the most profitable (most productive) activities discovered to date. Larger economies have more entrepreneurs 
engaged in discovery, and therefore, everything else being the same, will have maximum levels of productivity in tradables that are higher. ${ }^{3}$ And indeed, just as this theory predicts, country size does turn out to have a positive and statistically significant impact on EXPY, even when we control for income, human capital, and other plausible regressors. Hence, we can use this theoretical argument as a motivation for using measures of country size as an instrumental variable for EXPY. When we do this, we find the same result that we did with simple OLS regressions. Initial levels of EXPY are predictive of subsequent growth.

What is precisely the mechanism that makes EXPY a potent force for growth? The theory is that once investors in a country "discover" a number of high productivity exportables, this sets off a powerful demonstration effect. Other investors are drawn in, and as the sector and its suppliers expand, the economy's resources get pulled from lower productivity activities into higher productivity activities. This kind of growth driven by differential productivity across sectors and structural change lies at the root of China's economic performance. A visual indication of this is provided in Figure 8, which shows the progress of per-capita GDP in China alongside EXPY since 1992. As we saw previously, the "quality" of China's exports has increased somewhat, especially when compared to competitors. But when we plot EXPY alongside per-capita GDP, what really stands out is the stability of EXPY relative to per-capita GDP. Per-capita GDP has been rapidly converging to the productivity level of the country's export basket: it rose from $15 \%$ of EXPY to 35\% in 2003. This picture is strongly indicative of a process of productivity diffusion within the economy: the productivity gains associated with producing a set of sophisticated exportables is spread around the economy as labor moves across industries and across space to the higher productivity exportable activities.

\footnotetext{
${ }^{3}$ For a formal model of this process, see Hausmann, Hwang, and Rodrik (2006).
} 
Figure 8: Productivity Level of Exports and GDP per capita (log of PPP dollars)

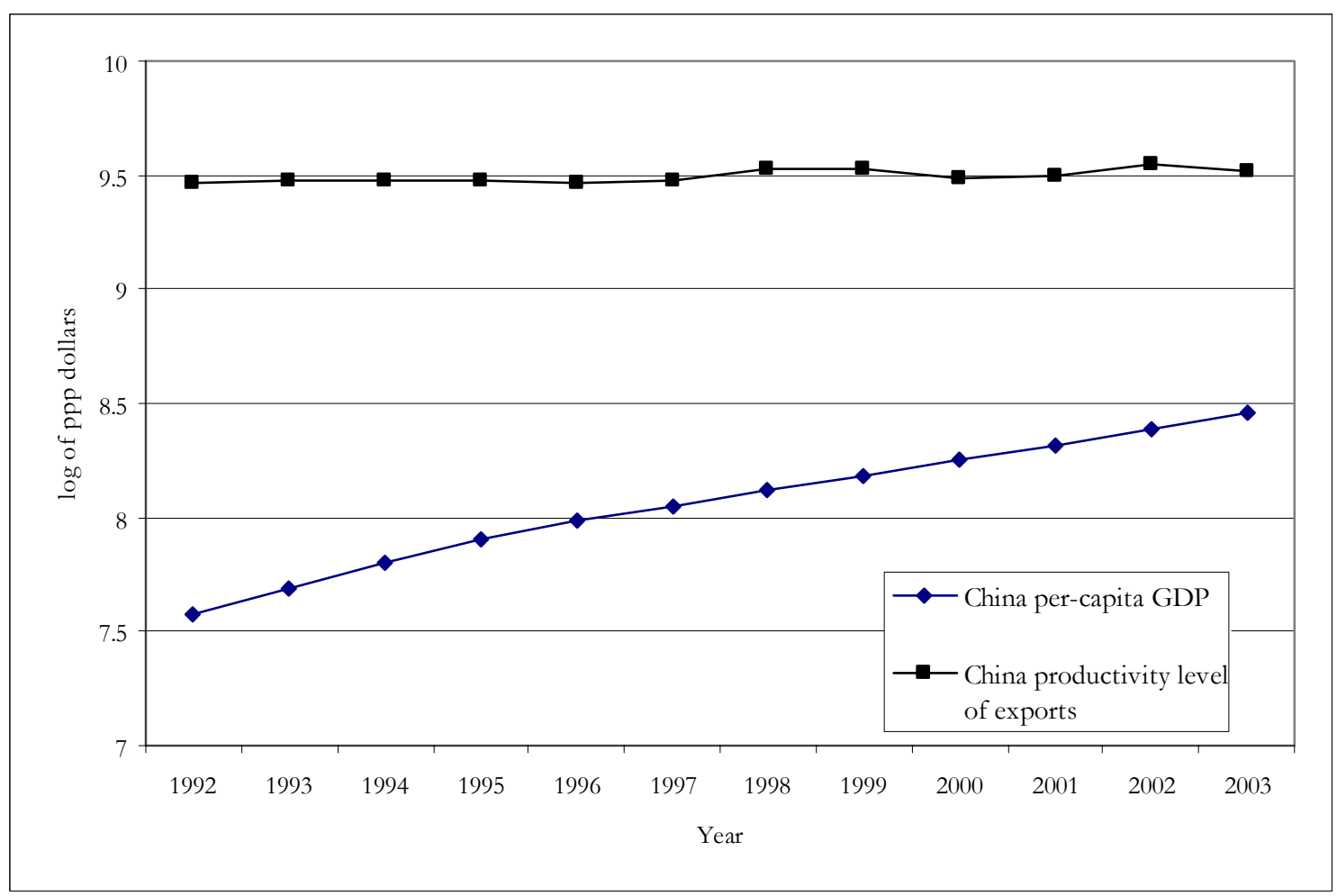

But the pattern shown in Figure 8 also raises a future challenge for China. If much of China's growth today is due to this particular pattern of convergence, will the economy not run out of steam once the process nears completion and the rest of the economy catches up to the productivity level of exportables? As we have seen, the “quality” of China's exportables has been increasing, but not nearly as rapidly as overall income. As a result, China is much less of an outlier today than it was in 1992 in terms of the cross-national relationship between income and EXPY (see Figure 9). Using the estimated coefficients from the growth regression presented earlier, this necessarily implies a significant growth slowdown in China. Furthermore, disaggregated analysis shows that the increase in China's EXPY level over time is accounted for exclusively by a compositional shift from goods associated with low productivity to goods associated with high productivity. New goods, that is goods that were not already exported in 
1992, have made a negligible contribution to the rise in overall EXPY. ${ }^{4}$ Sooner or later, therefore, China will have to "discover" new products to sell on world markets if growth is to continue at rates resembling recent ones. On the other hand, full GDP convergence to the current level of EXPY still implies a per-capita GDP for China that is much higher than today's level.

Figure 9: Relationship between EXPY and per-capita incomes in 2003 (restricted to same sample as in Figure 3)

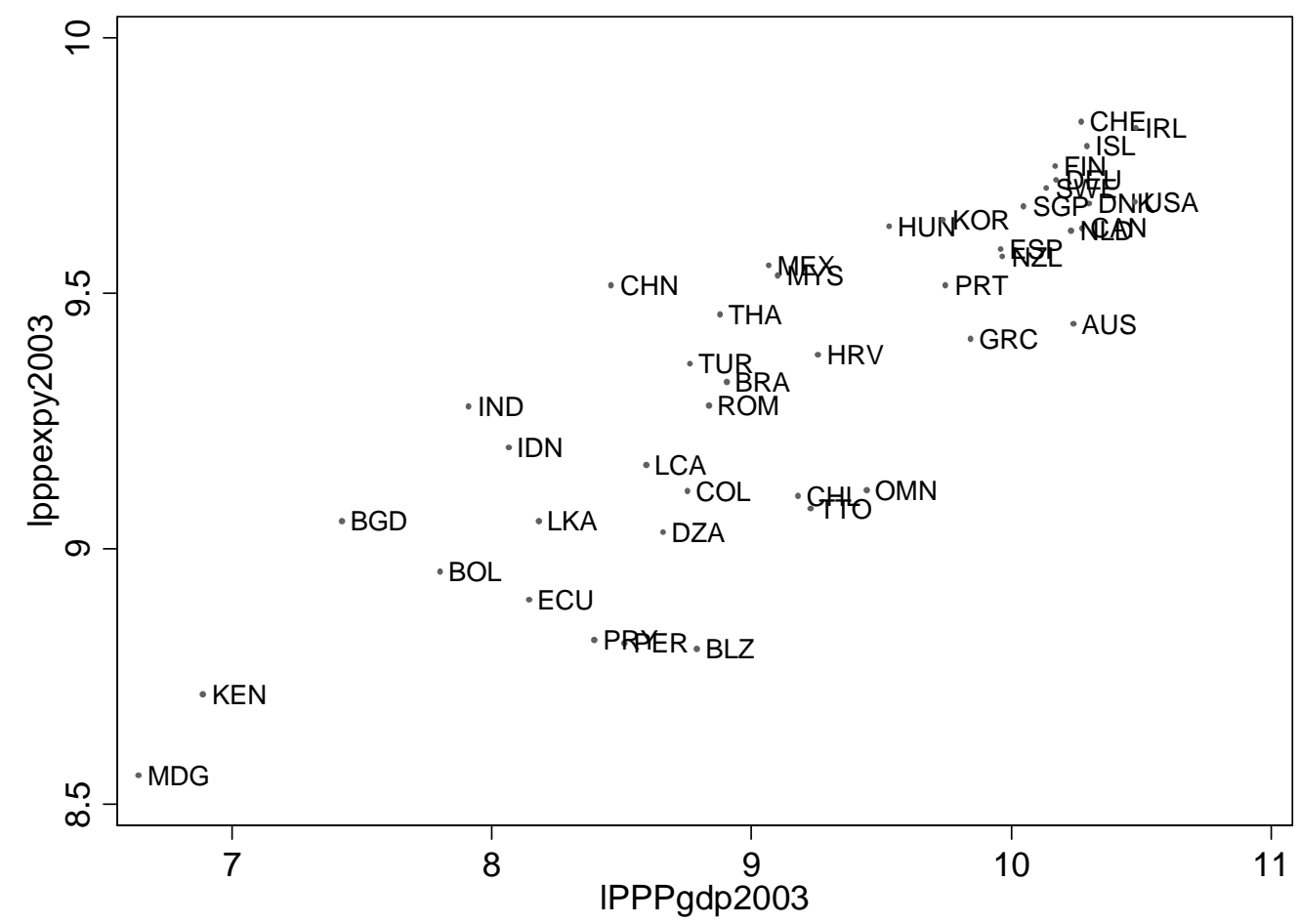

IV. The roots of success: consumer electronics

Among areas where China has been successful, consumer electronics stands out as one of those that would not have been expected a priori for a country at China's level of income. While low labor costs have helped, this cannot account for the entire story. Indeed, estimates by the

\footnotetext{
${ }^{4}$ Remember that the analysis here is carried out at the 6-digit level, so the absence of many new goods is meaningful.
} 
McKinsey Global Institute show that labor productivity in China's consumer electronics industry equals that in Mexico, a country where PPP-adjusted per-capita GDP is almost two times larger McKinsey 2003, 86). ${ }^{5}$ Furthermore, China has steadily moved away from being simply an assembler of components. Increasingly, production is integrated backwards and the supply chain is moving to where the assembly is undertaken. So China's success in consumer electronics is based on its ability to make a productivity jump. I will briefly discuss this case as it is emblematic of the broader statistical picture painted above.

Foreign investors have played a key role in the industry's evolution. They are the most productive of the producers, they are the source of technology, and they dominate exports. China's openness to foreign investment and its willingness to create special economic zones where foreign producers could operate with good infrastructure and with minimum hassles must therefore receive considerable credit. But if China has welcomed foreign companies, it has always done so with the objective of fostering domestic capabilities. To that end, China has used a number of policies to ensure that technology transfer would take place and strong domestic players would emerge. Early on, reliance was placed predominantly on state-owned national champions. Later, the government used a variety of carrots and sticks. Foreign investors were required to enter into joint ventures with domestic firms (in mobile phones and in computers). Domestic markets were protected to attract market-seeking investors, in addition to those that looked for cost savings. Weak enforcement of intellectual protection laws enabled domestic producers to reverse engineer and imitate foreign technologies with little fear of prosecution. And localities were given substantial freedoms to fashion their own policies of stimulation and support, which led to the creation of industrial clusters in particular areas of the country. Huchet characterizes China’s policies as of the mid-1990s thus: “China's technological acquisition

\footnotetext{
${ }^{5}$ It is also telling that China's EXPY exceeded Mexico's by 2003.
} 
strategy is clear: It allows foreign firms access to the domestic market in exchange for technology transfer through joint production or joint ventures” $(1997,270)$.

The end result of all this can be seen in an industry structure that is very different from the one, say, in Mexico. As Table 3 shows, domestic firms play a significant role in China. In fact, $100 \%$ foreign owned firms are a rarity among the leading players in the industry. Most of the significant firms tend to be joint ventures between foreign firms and domestic (mostly stateowned) entitities. A strong domestic producer base has been important in diffusing imported technologies and in creating domestic supply chains. In the words of the McKinsey Global Institute, “the international companies' interaction with domestic companies has created a genuine global success story” (McKinsey 2003, 79, emphasis added). 
Table 3: Major consumer electronics firms in China by ownership type

\begin{tabular}{|c|c|c|c|}
\hline Market segment & Foreign owned & Joint venture & Non-FDI \\
\hline Mobile phone & - $\quad$ Motorola & $\begin{array}{ll}\text { - } & \text { Motorola/Eastcom } \\
\text { - } & \text { Nokia/Capitel, } \\
& \text { Southern } \\
\text { - } & \text { Siemens/MII } \\
& \text { subsidiaries } \\
\text { - } & \text { Samsung/Kejian } \\
\text { - } & \text { SAGEM/Bird }\end{array}$ & - $\mathrm{TCL}$ \\
\hline PCs & $\begin{array}{ll}- & \text { HP } \\
\text { - } & \text { Dell }\end{array}$ & $\begin{array}{ll}\text { - } & \text { IBM/Great Wall } \\
\text { - } & \text { Toshiba/Toshiba } \\
& \text { Computer (Shanghai) } \\
\text { - } & \text { Epson/Start } \\
\text { - } & \text { Taiwan GVC/TCL }\end{array}$ & $\begin{array}{ll}\text { - } & \text { Lenovo (previously } \\
& \text { Legend) } \\
\text { - } & \text { Founder } \\
\text { - } & \text { Tongfang }\end{array}$ \\
\hline "Brown" goods & & $\begin{array}{ll}\text { - } & \text { Sony/SVA } \\
\text { - } & \text { Philips/Suzhou CTV } \\
\text { - } & \text { Toshiba/Dalian } \\
& \text { Daxian } \\
\text { - } & \text { Great Wall } \\
& \text { Electronics/TCL }\end{array}$ & $\begin{array}{ll}\text { - } & \text { Changhong } \\
\text { - } & \text { Konka } \\
\text { - } & \text { Hisense } \\
\text { - } & \text { Skyworth } \\
\text { - } & \text { Haier } \\
\text { - } & \text { Panda } \\
\text { - } & \text { Xoceco }\end{array}$ \\
\hline "White" goods & - $\quad$ Siemens & $\begin{array}{ll}\text { - } & \text { Samsung/Suzhou } \\
\text { - } & \text { Xiangxuehai } \\
& \text { Electrolux/Changsha } \\
\text { - } & \text { Zhongyi } \\
\text { - } & \text { Mitsubishi/Haier } \\
\text { - } & \text { Sanyo/Kelon, } \\
\text { - } & \text { Rongshida } \\
\text { - } & \text { Hong Leong } \\
\text { - } & \text { TosG)/Xinfei } \\
& \text { Toshiba } \\
& \text { Carrier/Midea }\end{array}$ & $\begin{array}{ll}\text { - } & \text { Changling } \\
\text { - } & \text { Gree }\end{array}$ \\
\hline
\end{tabular}

Source: McKinsey (2003), p. 83.

It is true that many of the Chinese companies created through government efforts ended up as failures. Accounts of industrial policy in China point to the low productivity and low technology absorption of many SOEs, and to the lack of coordination (across national ministries as well as across different levels of government) that characterizes Chinese policies (see Huchet 
1997, Kraemer and Dedrick 2001). But as in other areas of policy, government attitudes have been pragmatic and open to trying new approaches when old ones fail. A well-known case of failure was the early development of the color TV industry, which consisted in the 1980s of more than 100 companies operating at short production runs and high cost. By the early 1990s, the industry had been consolidated thanks to the efforts of local governments and national leadership, which forced mergers and joint ventures with foreign firms. This reversal of policies led to the emergence in quick order of a profitable, export-oriented industry (see Lo and Chan 1998).

Moreover, it is possible that the importance of the weaknesses of the Chinese bureaucratic model is exaggerated. The essence of the self-discovery model of economic development is that you need only a few successes: once a small number of high-productivity activities are identified, they act as the lever for economic convergence by pulling resources in from lower productivity activities. Without state support and publicly funded R\&D, a company like Lenovo (previously known as Legend) which became large and profitable enough to purchase IBM's PC business recently would never have come into being. ${ }^{6}$ Better to experiment and identify these higher-end activities than not try at all. Lack of coordination can be an advantage in these circumstances, as it allows different things to be tried and for successes in one region to be copied elsewhere. Somewhat paradoxically, the hesitant, gradual, often conflicting manner in which policies have been formulated and implemented in China may have presented a more suitable environment for entrepreneurial experimentation and cost discovery than one that is centralized, top-down, and overly coordinated.

In sum, China has benefited both from good fundamentals—low labor and materials costs, "outward orientation" in the form of SEZs, large market size—and from a determined

\footnotetext{
${ }^{6}$ Lenovo's majority owner is a state-owned entity.
} 
government effort to acquire domestic capabilities and build a modern industry. The large size of the economy has allowed policy experimentation. It also has allowed the government to use the carrot of the internal market to force foreign investors into joint ventures with domestic producers. If China is producing an increasingly sophisticated set of consumer electronics product, it would appear that this is due as much to the policy environment as it is to the free play of market forces.

While I have focused on the consumer electronics sector here, the same could be said of other export successes as well. For example, the auto parts industry has been heavily promoted through local content requirements. The Chinese government required foreign car companies investing in the market to achieve a relatively high level of domestic content within a short period of time (typically 70\% within three years) (Sutton 2005, 9). This forced these companies to cooperate closely with local suppliers to ensure that their technology and quality were up to par. In his study of the auto supply chain in China, John Sutton found that the domestic first-tier suppliers had achieved quality levels close to international best practice (Sutton 2005). One indicator of success is that China exported \$1.7 billion worth of auto components by 2001. Another is that none of the foreign car manufacturers intended to switch to imports, once domestic content requirements were phased out to comply with WTO rules. Sutton reports that "the view expressed in all cases was that the car-maker had developed local sources of supply that were superior, in terms of combination of cost and quality, to imported alternatives” (Sutton 2005, 25). Domestic-content requirements are widely derided as an inefficient tool of industrial policy. The Chinese case stands in stark contrast to this. ${ }^{7}$

\footnotetext{
${ }^{7}$ Sutton's portrayal of domestic content requirements in India is not much different; there too, it appears that these requirements helped promote a successful auto parts industry during the 1990s, prior to the coming into effect of WTO rules.
} 


\section{$\underline{\text { V. Implications }}$}

I close with three set of implications for Chinese policymakers. The first has to do with the need to understand better the fundamental underpinnings of China's export performance and its economic success. As I have argued above, much more than comparative advantage and "free markets” have been at play here. China's pattern of production and exports would have looked very different if the traditional forces of comparative advantage, pushing China to specialize in labor-intensive products “appropriate” to low income economies, were the sole determinant. Instead, China has ended up with an export basket that is significantly more sophisticated than what would be normally expected. Government policies have helped nurture domestic capabilities in consumer electronics and other advanced areas that would most likely not have developed in their absence. Whatever static inefficiency costs may have been engendered in the process, this has had favorable implications for China's growth. This is an important point to remember as the inevitable debate between "market fundamentalists” and "planners” plays itself out in the Chinese context.

The second implication has to do with the sustainability of China's export-oriented growth. The question here is whether, with exports-to-GDP so high and rising, the Chinese growth model is inevitably running out of steam. The ideas developed in this paper teach us that what matters for China's future growth is not the volume of exports or its relation to GDP, but the "quality" of these exports. Indeed, what is so special about China's exports is not that they are voluminous or that its large pool of labor gives it a huge labor cost advantage. What stands out is that China sells products that are associated with a productivity level that is much higher than a country at China's level of income. This helps account both for why China's trade is viewed as problematic in advanced countries, and for China's rapid economic growth. The 
economically relevant question for sustainability is not whether trade-GDP can keep on rising, but whether China will manage to latch on to higher- and higher-income products over time, and continue to fuel its growth thereby. As we have seen, there has been a dramatic reduction over the last decade in the gap between EXPY and per-capita GDP. Everything else being the same, this is something that is likely to slow down growth.

This brings us to the third point, having to do with the nature of future industrial policies. A clear implication of this paper is that China's industrial policies-however incoherent they may have been—have had a hand in China’s past success. Future economic performance may also need to be supported by such policies. This is of course also a lesson from the experience of other East Asian success stories: Japan, Taiwan, South Korea, and Singapore.

The usual criticism of industrial policy is that governments cannot pick winners, and therefore should not try. But this is not the right way to think about industrial policy. In environments that are rife with uncertainty and with technological and informational spillovers, markets under-provide investment in non-traditional products. The appropriate role for industrial policy is to fill in this market incompleteness by subsidizing investments in new products. It is a given that not all of these additional investments will prove to be socially profitable. Good industrial policy consists of withdrawing support from those projects that are revealed to be failures, so that resources do not get bottled up in unproductive activities. Hence the appropriate criterion of success for industrial policy is not that "only winners should be picked" (an impossible task) but that "losers should be let go" (a much less demanding and more doable task). The latter is the relevant yardstick against which industrial policies ought to be measured. Therefore, a key question for China going forward is whether Chinese policies will maintain their experimental and flexible nature-whether governments will remain willing to 
support new industries but also willing to turn against ventures that under-perform. Designing the appropriate institutional structure to foster such an experimental, carrot-and-stick approach to industrial policy is an important challenge facing Chinese policy makers. ${ }^{8}$ This is an area where institutional transplantation does not work very well. We can identify the higher-order principles involved at a sufficient level of generality, but need to fashion blueprints that are suited to the local context. The challenge for China therefore is to develop institutional models that are based on Chinese realities.

\footnotetext{
${ }^{8}$ In Rodrik (2004) I discuss some of the issues involved and present some broad guidelines drawing from examples in East Asia and Latin America.
} 


\section{Appendix: Construction of PRODY and EXPY}

$P R O D Y$ is the weighted sum of the per capita GDP of countries exporting a given product, and thus represents the income level associated with each of these goods. Let countries be indexed by $j$ and goods be indexed by $l$. For any given year, the value of total exports of country $j$ equals:

$$
X_{j}=\sum_{l} x_{j l}
$$

Let the per-capita GDP of country $\mathrm{j}$ be denoted by $Y_{j}$. Then the PRODY index for good $k$ is:

$$
\operatorname{PRODY}_{k}=\sum_{j} \frac{x_{j k} / X_{j}}{\sum_{j}\left(x_{j k} / X_{j}\right)} Y_{j}
$$

The numerator of the weight $x_{j k} / X_{j}$ is the value-share of the commodity in the country's overall export basket. The denominator of the weight, $\sum_{j}\left(x_{j k} / X_{j}\right)$, aggregates the value-share across all countries exporting the good. By using export share rather than export volume, the weighting scheme tries to ensure that adequate weight is given exports that are important to smaller poorer countries.

EXPY for country $i$ is given in turn by:

$$
E X P Y_{j}=\sum_{l} \frac{X_{j l}}{X_{j}} P R O D Y_{l}
$$

This is a weighted index of the representative income associated a country's exports, where the weight is simply the value share of the product in the country's total exports.

Our trade data comes from the United Nations Commodity Trade Statistics Database (COMTRADE). The dataset includes products at the 6-digit level in the Harmonized System for the years 1992 to 2003. The value of exports is measured in current US dollars, which we then convert to 2000 dollars for comparison with real GDP per capita series. The number of countries that report the trade data vary considerably from year to year. However, we construct the PRODY measure for a consistent sample of countries that reported trade data in each of the years 1999, 2000 and 2001. After deleting some missing observations, our data set consists of 5,023 PRODY observations. Note that we use the average PRODY from 1999-2001 to construct the EXPY index, so that the PRODY that go into the construction of EXPY themselves do not vary over the years. 


\section{REFERENCES}

Hausmann, Ricardo, and Dani Rodrik, “Economic Development as Self-Discovery,” Journal of Development Economics, December 2003.

Hausmann, Ricardo, Jason Hwang, and Dani Rodrik, “What You Export Matters,” NBER Working Paper, January 2006.

Huchet, Jean-Francois, "The China Circle and Technological Development in the Chinese Electronics Industry,” in B. Naughton, ed., The China Circle: Economics and Electronics in the PRC, Taiwan, and Hong Kong, Washington, DC: Brookings Institution Press, 1997.

Kraemer, Kenneth L., and Jason Dedrick, "Creating a Computer Industry Giant: China's Industrial Policies and Outcomes in the 1990s," Center for Research on Information Technology and Organizations, UC Irvine, 2001.

Lardy, Nicholas, “China: The Great New Economic Challenge?” Institute for International Economics, Washington, DC, 2004.

Lo, Dic and Thomas M. H. Chan, "Machinery and China's nexus of foreign trade and economic growth,” Journal of International Development, 10(6), 1998, 733-749.

Mayer, Jorg, and Adrian Wood, “South Asia’s Exports in a Comparative Perspective,” Oxford Development Studies, 29(1), 2001.

McKinsey Global Institute, New Horizons: Multinational Company Investment in Developing Economies, San Francisco, October 2003.

Prasad, Eswar, ed., China's Growth and Integration into the World Economy: Prospects and Challenges, IMF Occasional Paper 232, Washington, DC, 2004.

Rodrik, Dani, “Industrial Policy for the Twenty-First Century,” unpublished paper, Harvard University, September 2004 (http://ksghome.harvard.edu/ drodrik/UNIDOSep.pdf).

Sutton, John, "The Auto-Component Supply Chain in China and India: A Benchmarking Study," London School of Economics, unpublished paper, 2005. 